\title{
複合材料積層梁の層間はく離同定手法開発における はく離のモデル化の影響
}

\author{
稲田 貴臣*1, 島村 佳伸*2, 轟章*3, 小林 英男*4
}

(2000 年 11 月 14 日受付)

\author{
Effect of Delamination Modeling on Development of Delamination \\ Identification Method of Composite Laminated Beams
}

\begin{abstract}
Takaomi InAdA, ${ }^{* 1}$ Yoshinobu ShImamura, ${ }^{* 2}$ Akira TodorokI ${ }^{* 3}$ and Hideo KobAYASHi*4
(Received November 14, 2000)
\end{abstract}

Damage identification methods using vibration data have attracted attention as health monitoring systems of composite laminated structures. In many papers referred to damage identification methods using vibration data, damage is modeled in stiffness degradation regardless of damage modes. In health monitoring of real structures, identifying size and location of slight delamination, which accompany matrix cracks, is important. However, the relationship between the change of natural frequency caused by stiffness degradation and those caused by actual delamination is unknown. Then, unconfirmed applicability of damage identification method with stiffness degradation model to identifying delamination would be introduced. In the present study, the relationship between stiffness degradation and delamination is investigated in terms of factors that control the natural frequency changes of the structures by using FEM. Applicability of damage identification method to delamination identification is also examined.

\section{1. 緒}

複合材料積層板は層間強度が低く, 外部衝撃等により 層間はく離が形成されやすい，層間はく離は構造の圧縮 強度・剛性を大きく低下させるため, 構造健全性の評価 において層間はく離の位置，大きさの同定が重要とな る.そこで近年, 現場での簡便な非破壊検査手法として 振動デー夕を利用した損傷同定法が注目されてい $ろ^{1 \sim 8)}$.

振動デー夕を利用した複合材料の損傷同定法として, ニューラルネットワークを利用した手法 ${ }^{1,8)}$, フレキシ ビリティマトリックスを利用した手法 ${ }^{2)}$, 動的残差力を 利用した手法 ${ }^{3)}$ がある。これらの手法では，比較的低次

*1 *4 東京工業大学大学院理工学研究科（152-8552 東京 都目黒区大岡山 2-12-1)

Graduate School of Science and Engineering, Tokyo Institute of Technology, 2-12-1, O-okayama, Meguro-ku, Tokyo 152-8552, Japan

*1 大学院生 Graduate Student, ${ }^{* 2}$ 助手 Research Associate, ${ }^{* 3}$ 助教授 Associate Professor, ${ }^{* 4}$ 教授 Professor
モードの固有振動数や固有モードからニューラルネット ワークを利用して直接的に損傷を同定，あるいはフレキ シビリティマトリックスや動的残差力を計算し，損傷を 同定している.ここで, 損傷は剛性低下（弾性定数低 下）に置き換えられることが多く，繊維破断をともなう はく離損傷のように弾性定数低下が明確な損傷に対して は有効である。しかし，実機ではマトリックス割れのみ を伴う軽微なはく離損傷の同定も重要であり，この場合 には明確な弾性定数低下は生じない.この剛性低下で生 じる梁の動特性変化と軽微なはく離損傷で生じる梁の動 特性変化との関係は確認されておらず，また，開発した 損傷同定手法のはく離同定への適用性も検討されていな い.そのため，開発した損傷同定手法を実機に適用する 場合，剛性低下とはく離の関係の詳細な検討が不可欠で ある。

本研究ではマトリックス割れのみを伴う軽微なはく離 損傷を対象として，はく離を要素の剛性低下に置き換え た場合（要素剛性低下モデル），3次元的にはく離を作 成した場合（はく離モデル）の動特性の変化を有限要素 法で解析し，それぞれの動特性の支配因子から両者の関 


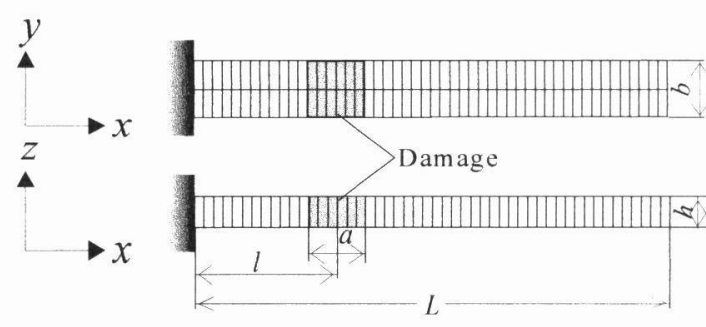

Normalized damage location: $/ / L$ Normalized damage size: $a / L$

Fig. 1 Stiffness degraded beam model.

係を検討した。簡単のため, CFRP 積層片持ち梁に幅 方向貫通はく離が存在する場合を想定し，従来の損傷同 定解析で広く利用され，実機でも測定が容易と推測され る 1 3 次モードの固有振動数変化にのみ着目した. ま た，要素剛性低下モデルで開発した損傷同定手法をはく 離同定に適用し，同定精度に対するはく離のモデル化の 影響を検討した.

\section{2. 固有振動数变化の原理}

一様断面の片持ち梁（全長 $L$ ) が自由振動する場合を 考える. 梁は均質な等方性材料からなるものとしてヤン グ率を $E$, 梁の断面 2 次モーメントを $I$, 単位長さあた りの質量を $\mu$ とすると, 梁の固有振動数は次式で表さ れる゙.

$$
\omega_{i}=\left(\frac{\lambda_{i}}{L}\right)^{2} \sqrt{\frac{E I}{\mu}} \quad(i=1,2, \cdots)
$$

式（1）において $\lambda_{i}$ は固有值であり，EIを曲げ剛性と 呼ぶ. 損傷後も質量は不変と仮定すると, 損傷発生によ る梁の曲げ剛性低下にしたがい固有振動数も低下寸るこ とが式（1）よりわかる.

ここで，損傷の大きさと損傷量（剛性低下量）を一定 とし, 損傷位置に対する固有振動数変化を考える.この とき, 損傷位置に依存して固有振動数低下量は変化す る 。すなわち，損傷の発生により損傷部分の曲げ剛性 が局所的に低下寸るが，それが梁全体の曲げ剛性に影響 しやすい部分としにくい部分が存在する。また，損傷位 置と損傷量は一定で損傷の大きさが変化する場合, 損傷 が大きいほど固有振動数の低下は顕著となる.

このように固有振動数は損傷の位置, 大きさに応じて 変化するため, 損傷同定パラメー夕として広く利用され ている ${ }^{1,8)}$. 本研究では, 実機でも測定が容易と推測さ れる 1 3 次モードの固有振動数変化にのみ着目する.
Table 1 Material properties of unidirectional CFRP lamina.

\begin{tabular}{ll}
\hline \hline Longitudinal modulus $E_{1}$ & $91.5 \mathrm{GPa}$ \\
Transverse modulus $E_{2}\left(=E_{3}\right)$ & $8.5 \mathrm{GPa}$ \\
Longitudinal shear modulus $G_{12}\left(=G_{13}\right)$ & $4.3 \mathrm{GPa}$ \\
Transverse shear modulus $G_{23}$ & $3.15 \mathrm{GPa}$ \\
Major Poisson's ratio $\nu_{12}\left(=\nu_{13}\right)$ & 0.31 \\
Transverse Poisson's ratio $\nu_{23}$ & 0.35 \\
Density $\rho$ & $1,466 \mathrm{~kg} / \mathrm{m}^{3}$ \\
\hline
\end{tabular}

\section{3. はく離損傷解析モデル}

本研究では汎用有限要素法プログラムANSYS Rev. 5.5 を使用し, はく離による梁の固有振動数変化を解析 する，前述のとおり，本研究ではマトリックス割れのみ を伴う軽微なはく離損傷を対象とする. 簡単のため, 直 交積層 CFRP 梁を対象とし, はく離を一様な剛性低下 に置き換えたモデル（要素剛性低下モデル），3次元的 にはく離を作成したモデル（はくく離モデル）を利用し て, はく離の位置, 大きさの変化に対寸る固有振動数変 化を解析し，それぞれの支配因子を検討する。

\section{1 要素剛性低下モデル}

要素剛性低下モデルでは, 任意要素の剛性を低下させ て損傷を模擬する。モデルの作成が容易であり, 複合材 料の損傷同定解析で広く利用されている( 3). 本研究で は，はく離と等価な分だけ剛性を低下させる。

解析対象は $x=0$ の位置を完全固定した片持ち梁と $L$, 梁の積層構成は $\left[0_{2} / 90_{2}\right] \mathrm{s}$, 長さ $L$, 幅 $b$, 厚さ $h$ はそれぞれ $240 \mathrm{~mm}, 19 \mathrm{~mm}, 1.45 \mathrm{~mm}$ とした（Fig. 1 参照)。贋ごとに瀻維配向角や厚さの定義が可能でモデ ル化が容易なことから, 要素には 8 節点四角形要素の積 層シェル要素（shell 99）を使用し, 梁の長手方向 ( $x$ 方向）を50 分割, 幅方向（ $y$ 方向）を2 分割して固有 振動数解析を実施した. 総要素数は 100 , 総節点数は 405 である。また, 解析に使用した一方向 CFRPラミ ナの材料定数を Table 1 に示す.

ここで，はく離発生に伴う曲げ剛性低下量を考える。 積層構成 $\left[\mathrm{O}_{2} / 90_{2}\right] \mathrm{s}$ の梁を 2 種類の材料からなる組み合 わせ梁とみなすと， $0^{\circ}$ 層のみで置き換えた梁断面は $E_{2} /$ $E_{1} \cong 0.1$ の関係から Fig. 2 (a) のようになる.このモデ ルにおいて，マトリックス割れを伴う片側 $0 / 90$ 層間の はく離を $90^{\circ}$ 層の消滅と近似した場合 (Fig. 2(b) 参照) の曲げ剛性低下量は約 $2 \%$ となることから, 本研究では 任意要素の各層の瀻維方向ヤング率 $E_{1}$ を一様に $2 \%$ 低 


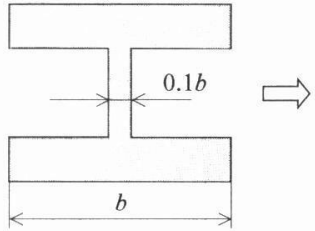

(a) Intact

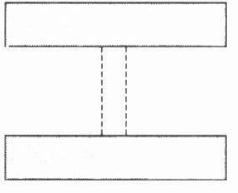

(b) Delaminated

Fig. 2 Equivalent cross section of the $\left[0_{2} / 90_{2}\right] \mathrm{s}$ beam assumed to composite beam.

下させてはく離による剛性低下を模擬した。便宜上，剛 性低下領域（以降，損傷と呼ぶ）の位置，大きさはそれ ぞれ梁の全長で正規化した值 $l / L, a / L$ で表現する. 例えば，Fig. 1 の場合には，損傷の位置，大きさはそれ ぞれ $0.3,0.12$ となる。

\section{2 層間はく離モデル}

層間はく離モデルでは各層のヤング率は変更せず，3 次元的にはく離き裂をモデル化した (Fig. 3 参照)。梁 の寸法, 積層構成等は Fig. 2 の要素剛性低下モデルと 同一であるが，はく離き裂を作成するために 2 つの梁を 貼り合わせて作成した。その手順を以下に示す。

まず，積層シェル要素を用いて積層構成が $\left[0_{2} / 90_{4}\right]$ と $\left[0_{2}\right]$ の 2 つの梁を作成し, 積層構成が $\left[0_{2} / 90_{2}\right] \mathrm{s}$ と なるようにこれらを上下に重ねる。このとき，上側の梁 $\left(\left[0_{2} / 90_{4}\right]\right)$ の節点を梁下面，下側の梁 $\left(\left[0_{2}\right]\right)$ の節点 を梁上面に配置し，上下の要素の節点を同一位置に配置 する。 そして，はく離部以外では上下の要素の節点同士 を完全に結合し，はく離部では上下の梁が同位相で振動 するように拘束を加え，一部の片側 0/90 層間にはく離 を有する CFRP 積層梁を模擬した。はく離部に扔いて その他の自由度の拘束はなく, はく離上下の梁はそれぞ れ独立に伸縮可能である。な拉，90層のマトリックス 割れが固有振動数に与える影響は小さいと考えられるた め, 本モデルでは考慮していない。要素分割は要素剛性 低下モデルと同一であり，梁が 2 枚となるため総要素数 は 200, 総節点数は 810 となる.

\section{4. 応答曲面による損傷同定法}

固有振動数変化から損傷の位置，大きさを直接同定す る逆問題に, 従来はニューラルネットワークが利用され てきた1,8).しかし，ニューラルネットワークでは学習 に多くの時間が必要であり, 得られた入出力関係の統計 的検定は不可能であるため, 教師信号以外の解は必ずし も保証されていない。また，実機では高精度な損傷同定

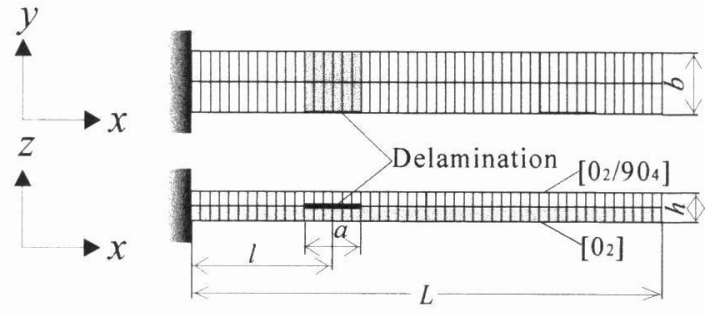

Normalized delamination location: $/ / L$ Normalized delamination size: $a / L$

Fig. 3 Delaminated beam model.

よりも簡単ですばやい同定が望ましいと考えられ，本研 究では応答曲面法を利用する。応答曲面法は逆問題に対 してもニューラルネットワークとほほ同等の性能である ことが確認されている

応答曲面法は影響因子を用いた応答の近似式を求める ために適用される手法であり，製品プロセスの最適化な ど品質工学の分野で古くから用いられてきた ${ }^{11}$. 応答曲 面法は最小二乗法による曲面回㷌と, 誤差の小さい応答 曲面を得るための測定点を決定する実験計画からなる。 今回は単純構造の片持ち梁が対象であるため, 実験計画 は利用していない。

簡単なことから，応答曲面には多項式が利用されるこ とが多い。例として，2 次多項式の応答曲面を考える。

このとき，応答曲面は次式で表される。

$$
y=\beta_{0}+\sum_{j=1}^{n} \beta_{j} x_{j}+\sum_{j=1}^{n} \beta_{j j} x_{j}^{2}+\sum_{i=1}^{n-1} \sum_{j=i+1}^{n} \beta_{i j} x_{i} x_{j}
$$

この式は簡単な線形回㷌モデルに変換可能であり, 未知 係数 $\beta$ は最小二乗法で計算できる.

ここで， $k$ 個の測定点とその応答 $y_{i}(i=1, \cdots, k)$ が 与えられている場合を考える。このとき, $p$ 個の変数の 重回帰モデルは次式で表現される。

$$
\begin{array}{ccc}
\mathbf{y} & =\mathbf{X} \beta+\varepsilon \\
\mathbf{y}=\left\{\begin{array}{c}
y_{1} \\
y_{2} \\
\vdots \\
y_{k}
\end{array}\right\} & \mathbf{X}=\left[\begin{array}{ccccc}
1 & x_{11} & x_{12} & \cdots & x_{1 p} \\
1 & x_{12} & x_{22} & \cdots & x_{2 p} \\
\vdots & \vdots & \vdots & \ddots & \vdots \\
1 & x_{k 1} & x_{k 2} & \cdots & x_{k p}
\end{array}\right] \\
\beta=\left\{\begin{array}{c}
\beta_{1} \\
\beta_{2} \\
\vdots \\
\beta_{p}
\end{array}\right\} & \boldsymbol{\varepsilon}=\left\{\begin{array}{c}
\varepsilon_{1} \\
\varepsilon_{2} \\
\vdots \\
\varepsilon_{k}
\end{array}\right\}
\end{array}
$$

ここで， $\mathbf{y}$ は $k$ 個のモデルから解析された応答の列ベク トルで，X $k$ 個の測定点の集合である。また， $\beta$ は 重回㷌の係数べクトルであり，とは誤差べクトルであ 
る.

最小二乗法より， $\beta$ の期待值は次式で表される.

$$
\boldsymbol{\beta}=\left(\mathbf{X}^{T} \mathbf{X}\right)^{-1} \mathbf{X}^{T} \mathbf{y}
$$

応答曲面の近似精度を評価するための指標として, 重 回帰分析等で使用されている自由度修正済み決定係数が ある.一般に，モデルの総平方和 $S_{y y}$ は次式のように回 帰による平方和 $S S_{R}$ と残差平方和 $S S_{E}$ に分解できる。

$$
S_{y y}=S S_{R}+S S_{E}
$$

このとき, 自由度修正済み決定係数は次式で表される。

$$
R_{\mathrm{adj}}^{2}=1-\frac{S S_{E}}{S_{y y}} \cdot \frac{k-1}{k-p}
$$

したがって, 近似精度が高いほど $R_{\mathrm{adj}}^{2}$ の值が 1 に近づ $<$.

本研究では, 梁の固有振動数から損傷 (はく離) の位 置, 大きさを同定する逆問題に対して応答曲面法を適用 する. 式（2）において説明変数 $x$ を 1 3 次モードの 固有振動数とし, 被説明変数 $y$ が損傷の位置, 大きさ の応答曲面をそれぞれ作成する。ただし，損傷の位置， 大きさと固有振動数変化との関係は複雑なことから，応 答曲面には 3 次多項式を利用する。

\section{5. 結果と考 察}

\section{1 固有振動数变化の解析}

Fig. 1 の要素剛性低下モデルにおいて, 損傷の大きさ を $0.04 〜 0.14$ の範囲（刻み幅：0.02），位置を0〜1の 範囲（刻み幅：0.1）で変化させたときの 1 〜 次モード の固有振動数変化を順にFig. $4(\mathrm{a}) \sim(\mathrm{c})$ に示す。ま た，Fig. 3 の層間はく離モデルにおいて，はく離の位 置・大きさを同様に変化させたときの 1 3 次モードの固 有振動数変化を順に Fig. 5(a)〜 (c) に示す. 簡便のた

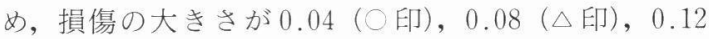

・印) の 3 種類の結果のみを示した。損傷（はく離） に伴う各モードの固有振動数変化の様子を明確にするた め，Fig. 4，5 では横軸に梁の全長で正規化した損傷 (はく離) 位置をとり，縦軸に $[-1,1]$ の範囲に正規 化した梁の固有振動数 $\bar{\omega}_{(i)}(i=1,2,3)$ を示した.ここ で，任意のはく離を有する梁の固有振動数を $\omega_{(i)}$ とす ると，正規化固有振動数 $\bar{\omega}_{(i)}$ は次式で計算される.

$$
\bar{\omega}_{(i)}=\frac{2 \omega_{(i)}-\left(\omega_{\max (i)}+\omega_{\min (i)}\right)}{\omega_{\max (i)}-\omega_{\min (i)}} \quad(i=1,2,3)
$$

式(7) において， $\omega_{\max (i)}, \omega_{\min (i)}$ はそれぞれ前述の解析 範囲内における損傷 (はく離) 梁の固有振動数の最大 值, 最小值であり, $\bar{\omega}_{(i)}$ は $\omega_{(i)}=\omega_{\max (i)}$ のときに最大值 $1, \omega_{(i)}=\omega_{\min (i)}$ のときに最小值一1をとる.

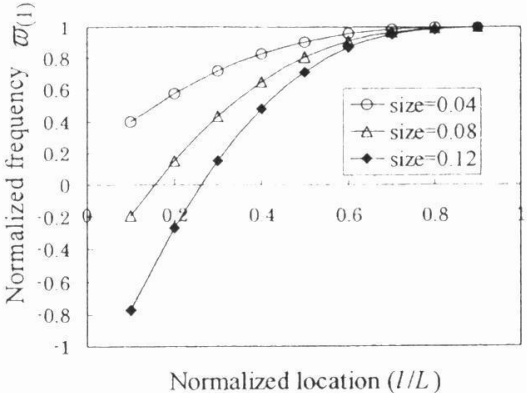

(a) 1 st mode

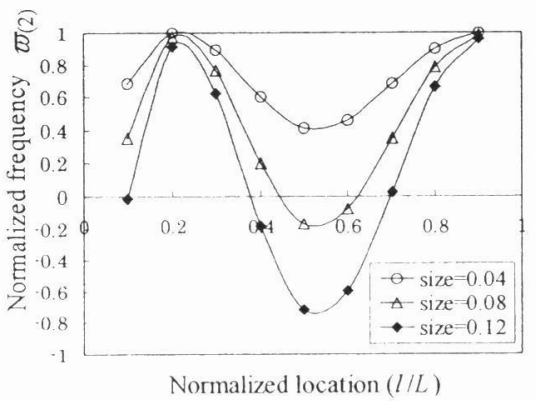

(b) 2nd mode

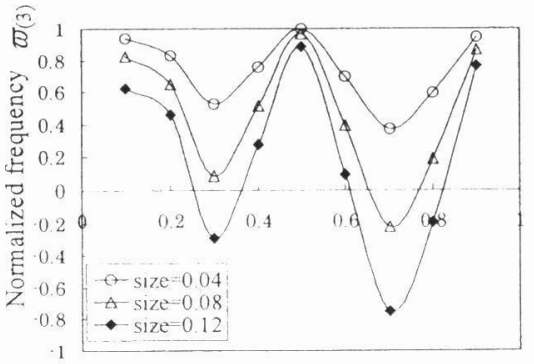

Normalized location $(I / L)$

(c) $3 \mathrm{rd}$ mode

Fig. 4 Effect of damage location on natural frequencies of the stiffness degraded beam model.

損傷（はく離）位置に対する固有振動数変化を考え る. Fig. 4，5より大きさが一定の場合，高次モードで あるほど固有振動数変化は複雑となる.Fig. 4 では変位 モード形状の腹に相当する部分，すなおち，2次モード (Fig. 4(b)) では 0.5 付近，3 次モード (Fig. 4(c)) で は $0.3,0.7$ 付近に損傷がある場合の固有振動数低下量 が大きいのに対し，Fig. 5 の同じ位置における固有振動 数低下はほとんどない. 変位モード形状の腹（2次モ一 


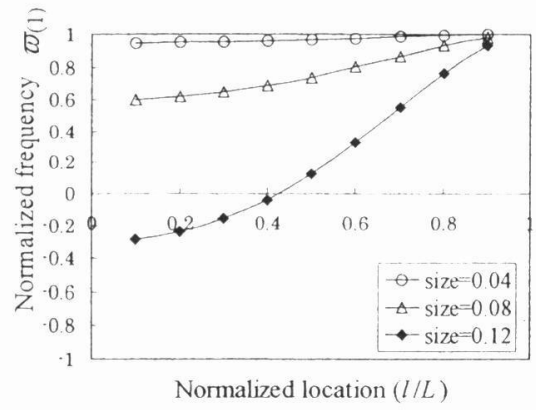

(a) 1st mode

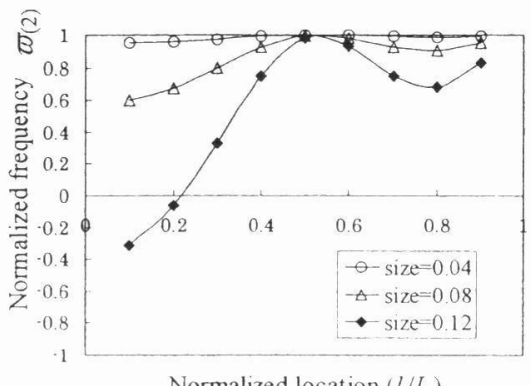

(b) 2nd mode

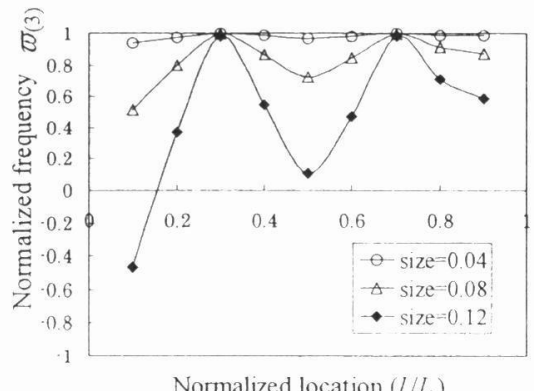

(c) 3rd mode

Fig. 5 Effect of delamination location on natural frequencies of the delaminated beam model.

ドでは $x / L=0.5$ 付近, 3 次モードでは $x / L=0.3,0.7$ 付近）では変位が極大であると同時に，ひずみが極大， せん断力が極小となることから, Fig. 4 亿示す要素剛性 低下モデルの固有振動数変化は損傷部のひずみ，Fig. 5 に示すはく離モデルの固有振動数変化はせん断力の大き さに依存すると推測される。ここで，Tracyらによる はく離梁の曲げ剛性解析では, 剛性低下量ははく離部に 作用するせん断力に支配されると報告されている!2). し
たがって，実際のはく離に伴う梁の固有振動数変化は, はく離モデルの解析結果と定性的に近いと推測される. な抢，損傷（はく離）の大きさに対しては，モードに関 係なく損傷が大きいほど固有振動数低下量が増大する。 位置が一定ならば，損傷が大きいほど梁全体の剛性に及 ぼす影響が大きいためである。

以上より，実際のはく離に伴う梁の固有振動数低下量 は，はく離の大きさだけでなくせん断力の大きさで決定 される。これに対し，はく離を等価な剛性低下に置き換 えた要素剛性低下モデルの固有振動数低下量は損傷の大 きさとひずみの大きさで決定され，各振動モードの梁の ひずみ分布とせん断力分布は異なるため，実際のはく離 による固有振動数変化を模擬できない。

\section{2 損傷同定解析}

複合材料積層構造の健全性評価では，層間はく離の位 置，大きさの同定が重要となる，本節では，要素剛性低 下モデルで作成した損傷同定手法をはく離同定に適用 し，同定精度に対するはく離のモデル化の影響を検討す る.

まず，要素剛性低下モデルの解析結果から応答曲面を 作成し，それを直接はく離同定に利用する場合を考え る。手順を以下に示す。

5.1 節で求めた要素剛性低下モデルの固有振動数解析 結果（デー夕数： 54 点）を利用して, 固有振動数から 損傷の位置，大きさを同定する応答曲面をそれぞれ作成 する。ただし，実機では高精度のはく離同定が要求され ないことと，簡便性を考慮して水準を利用した。損傷位 置は $0<l / L \leq 0.33,0.33<l / L \leq 0.66,0.66<l / L<1$ の3水準，大きさ泣 $0<a / L \leq 0.07,0.07<a / L \leq$ $0.11,0.11<a / L \leq 0.15$ の 3 水準とし, 水準化後のデ 一夕から応答曲面を作成した。同定用パラメー夕はそれ ぞれ式 (7) を用いて $[-1,1]$ に正規化した 1 3 次モ一 ドの固有振動数とし, 応答曲面には 3 次多項式を利用し た。作成した応答曲面の $R_{\mathrm{adj}}^{2}$ 值は位置, 大きさの順に それぞれ $0.936,0.682$ である。

応答曲面の近似精度を確認するため, 要素剛性低下モ デルの固有振動数から位置を同定した結果を Fig. 6 (a) に，大きさを同定した結果をFig. 7(a) に示す。ここ で，同定に使用したデー夕は応答曲面作成に使用したも のと同一である。そして，はく離同定性能の検証のた め, 5.1 節で求めたはく離モデルの固有振動数から位置 を同定した結果を Fig. 6(b) に，大きさを同定した結果 をFig. 7(b) に示す。ここで，要素剛性低下モデルとは く離モデルでは固有振動数低下量（絶対值）が異なるた 


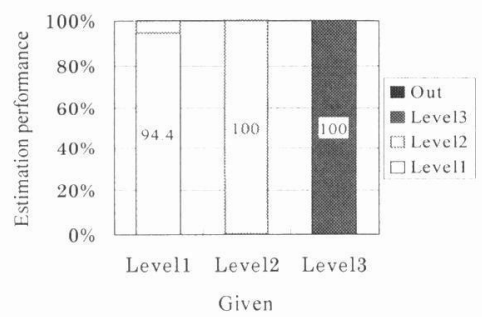

(a) Regressed from SD model data - identified for SD model data

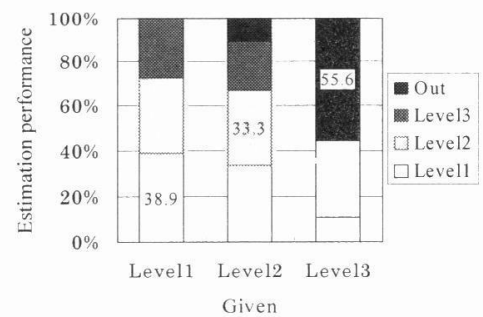

(b) Regressed from SD model data - identified for DL model data

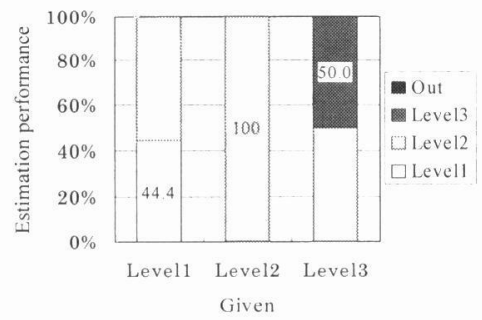

(c) Regressed from DL model data - identified for DL model data

Fig. 6 Identification results of damage (delamination) locations (SD model: stiffness degraded beam model, DL model: delaminated beam model).

め，はく離モデルの固有振動数であらかじめ式（7）を 用いて $[-1,1]$ に正規化後のデー夕を各応答曲面に代 入した.Fig. 6，7では横軸に実際の水準をとり，縦軸 には同定された水準の割合を全体で $100 \%$ となるように 表示した。ただし，あらかじめ規定したどの水準にも含 まれない場合はOutと表現した。

要素剛性低下モデルの固有振動数に対する位置の同定 率，すなわち，実際の水準と同定された水準が一致した 割合は水準 1 から順に 94.4\%，100\%，100\%（Fig. 6 (a) 参照)，大きさの同定率は水準 1 から順に $72.2 \%$, 94.4\%，88.9\%（Fig. 7(a) 参照）であり，位置，大き さともに高い同定率を有する。しかし，はく離モデルの 固有振動数に対する位置の同定率は水準 1 から順に

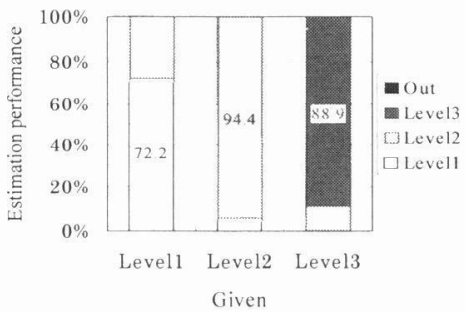

(a) Regressed from SD model data - identified for SD model data

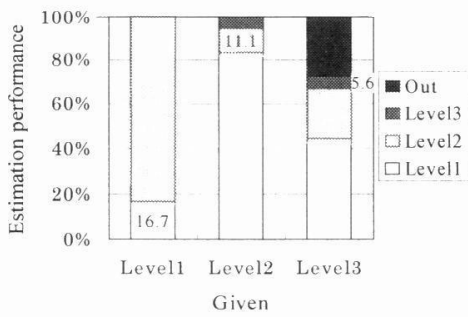

(b) Regressed from SD model data - identified for DL model data

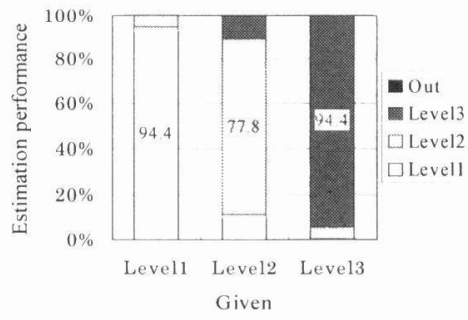

(c) Regressed from DL model data - identified for DL model data

Fig. 7 Identification results of damage (delamination) sizes (SD model: stiffness degraded beam model, DL model: delaminated beam model).

$38.9 \%, 33.3 \%, 55.6 \%$ (Fig. 6(b) 参照), 大きさの 同定率は水準 1 から順に 16.7\%，11.1\%，5.6\%（Fig. 7 (b) 参照）と（a）に比べて大幅に低下しており，実 用的でない。さらに，大きさについては実際よりも小さ く同定される傾向がある。前述のと抢り，要素剛性低下 モデルとはく離モデルでは固有振動数低下の支配因子が 異なるため，同定用パラメータとして1〜3 次モードの 固有振動数を用いる場合, 要素剛性低下モデルの解析結 果で作成した応答曲面によるはく離同定は不可能であ 万。

次に，要素剛性低下モデルを利用してはく離同定に必 要なパラメータ, 応答曲面の次数を決定した後, はく離 モデルの解析データで応答曲面を再度作成し，はく離を 
同定する場合を考える。

5.1 節で求めたはく離モデルの固有振動数解析結果を 利用して, 前述の方法にしたがい固有振動数からはく離 の位置，大きさを同定する応答曲面をそれぞれ作成し た。作成した応答曲面の $R_{\mathrm{adj}}^{2}$ 值は位置，大きさの順に それぞれ $0.258,0.793$ である。

はく離モデルの固有振動数に対する位置の同定結果を Fig. 6 (c)，大きさの同定結果をFig. 7 (c) に示す.ここ で，同定に使用したデー夕は応答曲面作成に使用したも のと同一である。位置の同定率は水準 1 から順に $44.4 \% ， 100 \% ， 50.0 \%$ ，大きさの同定率は水準 1 から 順に $94.4 \% ， 77.8 \% ， 94.4 \%$ あるる。位置の同定率は Fig. 6（a）に比へてて低く，また，実際の位置水準に関係 なく水準 2 に同定される傾向が強い，一方，大きさにつ いては，Fig. 7(a) と同等の同定率を有している.した がって, はく離の大きさは $1 \sim 3$ 次モードの固有振動数 から同定可能であるが，位置の同定にはパラメー夕の追 加が必要である。

以上より，要素剛性低下モデルの固有振動数変化と実 際のはく離による固有振動数変化は異なるため, 要素剛 性低下モデルの固有振動数変化で開発した損傷同定手法 によるはく離同定は不可能である。この場合，実際より も小さく同定される危険性がある。また，はく離モデル の解析結果で作成した応答曲面を用いてもはく離位置の 同定が困難なことから，要素剛性低下モデルの解析結果 で損傷同定法を検討する場合，実際のはく離同定に必要 なパラメー夕を正しく選択できない。この場合，損傷同 定手法の再検討が必要となり, コストの増加は避けられ ない.したがって，はく離同定手法の開発には，はく離 を適切に模擬した解析モデルが必要である.

\section{6. 結}

\section{言}

マトリックス割れのみを伴う軽微なはく離損傷を対象 として，はく離を剛性低下に置き換えた場合と実際のは く離による梁の固有振動数変化を解析し，その支配因子 から両者の関係を検討するとともに，剛性低下に置き換
えて開発した損傷同定手法のはく離同定への適用性を検 討した，得られた結論を以下に示す。

（1）実際のはく離による梁の固有振動数低下の支配因 子は，はく離の大きさとはく離部に作用するせん断力で あるのに対し，剛性低下に置き換えた場合の支配因子は 損傷の大きさとひずみであり，剛性低下では実際のはく 離による固有振動数変化を再現できない.

（2）はく離を剛性低下に置き換えて開発した損傷同定 手法によるはく離同定は不可能であり, はく離同定手法 の開発には実際のはく離を適切に模擬した解析モデルが 必要である.

\section{参 考 文 献}

1）邊 吾一, 西 恭一, 黄 一正, 藤川由美: 機論 A, 62, 602 (1996), 2338-2343.

2）邊 吾一, 山口達也, 福田行義, 青木義男, K.C. Park：機論 A, 66, 644 (2000), 721-726.

3）荻 芳郎, 福永久雄, 龟山正樹：日本複合材料学会 誌，26, 6 (2000)，236-242.

4）福永久雄, 関根英樹, 笹島圭輔, 胡 寧: 機論 C, 65, 635 (1999), 2617-2622.

5）金原 勲，影山和郎，鈴木敏郎，大沢 勇，伊出浩 司：材料, 43, 487 (1994), 476-481.

6) S.K. Thyagarajan, M.J. Schulz \& P.F. Pai : J. Sound \& Vibration, 210, 1 (1998), 162-170.

7) J. Maeck \& G. De Roeck: Key Engineering Materials, 167-168 (1999), 320-327.

8）例えば, A. Chukwujekwu Okafor, K. Chandrashekhara \& Y.P. Jiang: Smart Mater. Struct., 5 (1996), 338-347.

9）近藤恭平：工学基礎 振動論, 培風館 (1993), pp. $126-133$

10）轟章：第 4 回最適化シンポジウム講演論文集, 日本機械学会 (2000), pp. 217-222.

11) R.H. Myers \& D.C. Montgomery : Response Sur face Methodology: Process and Product Optimiza. tion Using Designed Experiments, John \& Sons, Inc. (1995).

12) J.J. Tracy: Thin-Walled Structures, 6 (1988), 371-383. 